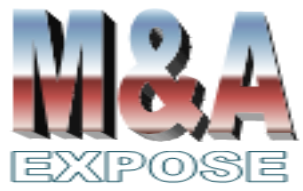

http://jurnal.usahid.ac.id/index .php/accounting
${ }^{1}$ Program Pascasarjana Universitas Trisakti nitafebina@gmail.com

\section{Pengaruh Tax Planning dan Investment Opportunity Set terhadap Firm Value dengan Good Corporate Governance sebagai Variabel Moderasi}

\author{
Anita Febina Permana ${ }^{\top}$
}

\section{Abstrak}

Penelitian bertujuan menguji pengaruh perencanaan pajak dan set peluang investasi pada nilai perusahaan dengan tata kelola perusahaan yang baik sebagai variabel moderasi. Penelitian ini dilakukan pada perusahaan yang terdaftar pada Indeks LQ-45 di Bursa Efek Indonesia, di mana sampel terdiri dari 90 observasi. Teknik analisis menggunakan Regresi Data Panel. Hasil penelitian menunjukkan bahwa perencanaan pajak dan set peluang investasi secara parsial memiliki pengaruh positif dan signifikan terhadap nilai perusahaan. Sementara itu tata kelola perusahaan yang baik dapat memoderasi pengaruh perencanaan pajak dan peluang investasi terhadap nilai perusahaan secara negatif.

Kata kunci : perencanaan pajak, set peluang investasi, tata kelola perusahaan yang baik, nilai perusahaan.

\section{Abstract}

The study aims to examine the effect of tax planning and investment opportunity sets on firm value with good corporate governance as a moderating variable. This research was conducted on companies listed on the LQ-45 Index on the Indonesia Stock Exchange, where the sample consisted of 90 observations. The analysis technique uses Panel Data Regression. The results showed that tax planning and investment opportunity sets partially had a positive and significant effect on firm value. Meanwhile good corporate governance can negatively influence the effect of tax planning and investment opportunities on company value.

Keywords: tax planning, investment opportunity set, good corporate governance, firm value 


\section{PENDAHULUAN}

Good Corporate Governance (GCG) adalah mekanisme untuk mengarahkan dan mengendalikan suatu perusahaan agar operasional perusahaan berjalan sesuai dengan harapan para pemangku kepentingan. Inti pelaksanaannya untuk memberikan nilai lebih kepada para pihak yang berkepentingan dalam perusahaan dengan memperhatikan beberapa prinsip. Menurut Soedaryono \& Riduifana (2013) GCG juga berdampak langsung terhadap nilai perusahaan. Menurut hasil survei Asian Corporate Governance Association (ACGA) pada 11 negara terhadap pelaku bisnis asing di Asia tahun 2017, Indonesia ditempatkan sebagai negara terburuk di bidang corporate governance. Data tersebut menunjukkan bahwa di Asia Tenggara, Indonesia menjadi negara dengan tingkat perlindungan terburuk terhadap investor (Herlambang, 2017).

Good Corporate Governance (GCG) merupakan tata kelola manajemen yang baik di suatu perusahaan dalam pengelolaan manajemen modal dan aset agar menarik para investor. Jika dalam pengelolaannya dilakukan dengan sangat baik, maka dapat memaksimumkan nilai perusahaan. Namun, corporate governance menjadi titik lemah pada perusahaan-perusahaan di negara berkembang. Hal ini disebabkan karena institusi yang berperan penting dalam mengawasi dan menjamin efisiensi dan integritas pasar belum berfungsi dengan baik. Kesenjangan informasi sangat mencolok, para pelaku pasar kurang berpengalaman, dan meskipun ada undang-undang tetapi tidak mampu mengatur dengan efektif dan independen karena mental korupsi, kelemahan sistem peradilan, dan konsep transparansi tidak diterapkan dengan baik (Herlambang, 2017).

Memaksimalkan nilai perusahaan sangat penting artinya bagi perusahaan, karena dengan memaksimalkan nilai perusahaan berarti juga memaksimalkan tujuan utama perusahaan. Meningkatnya nilai perusahaan adalah sebuah prestasi yang sesuai dengan keinginan pemiliknya karena sejalan dengan kesejahteraan para pemiliknya (Kristianto et al., 2017). Selain kesejahteraan pemilik dan stakeholder terkait, seiring dengan peningkatan nilai perusahaan, maka meningkat pula kewajiban yang harus dibayarkan kepada negara, yaitu kewajiban perpajakan.

Selain tata kelola perusahaan, perencanaan pajak juga merupakan faktor yang mempengaruhi nilai perusahaan. Perencanaan pajak merupakan tindakan yang dilakukan wajib pajak untuk meminimalkan kewajiban pajak yang akan dibayarkan dengan memanfaatkan kelemahan-kelemahan dalam aturan perpajakan yang sudah jelas diatur oleh undang-undang. Terdapat tiga hal yang harus diperhatikan dalam perencanaan pajak yaitu tidak melanggar aturan perpajakan, secara bisnis masuk akal, dan bukti pendukung memadai (Suandy, 2011; Dewanata, 2016). Tidak hanya perusahaan yang diuntungkan tetapi pemegang saham selaku pemilik perusahaan merasakan dampak positif perencanaan pajak. Pemegang saham membutuhkan perencanaan pajak yang tepat dengan memperhatikan biaya dan keuntungannya supaya tidak menurunkan risiko perusahaan (Armstrong, 2015). Selain perencanaan pajak, investasi pun merupakan salah satu faktor yang dapat meningkatkan nilai perusahaan. Investasi memberikan kesempatan perusahaan berkembang lebih maju, namun terkadang perusahaan tidak selalu mengambil kesempatan investasi di masa yang akan datang. Kesempatan berinvestasi memberikan gambaran tentang prospek investasi suatu perusahaan di masa mendatang, yang sangat berguna bagi investor sebelum menginvestasikan dananya (Herlambang, 2017). 
Wahab (2012) menyatakan bahwa perencanaan pajak berpengaruh negatif terhadap nilai perusahaan. Rizqia, et al. (2013) menunjukkan bahwa Investment Opportunity Set (IOS) berpengaruh positif signifikan terhadap nilai perusahaan. Temuan tersebut didukung Pratiska (2013) yang menyatakan IOS berpengaruh positif signifikan terhadap nilai perusahaan. Keputusan investasi yang dibuat oleh manajemen akan memengaruhi cara pandang investor dan pemilik perusahaan sehingga mempengaruhi nilai perusahaan. Pengaruh IOS terhadap nilai perusahaan didasarkan pada signaling theory di mana perusahaan akan memberikan sinyal positif terhadap investor, sehingga investor akan memberikan respon positif pula terhadap perusahaan yang memiliki IOS tinggi, karena lebih menjanjikan return di masa mendatang. Investor yang menyukai risiko telah mengerti bahwa return tinggi sejalan dengan tingkat risiko yang tinggi pula.

Hidayat \& Hairi (2016) menemukan hubungan negatif signifikan antara perencanaan pajak terhadap nilai perusahaan. Pengaruh negatif ini didasari bahwa pihak investor menginginkan pengembalian yang tinggi dari hasil investasi mereka. Penelitian mengenai pengaruh IOS terhadap nilai perusahaan dengan GCG sebagai variabel moderasi telah beberapa kali dilakukan. Gustiandika \& Hadiprajitno (2014) yang menyatakan bahwa GCG tidak mampu memoderasi hubungan antara IOS dengan nilai perusahaan. Hal ini bertolak belakang dengan Widyaningrum (2017) yang menyatakan bahwa GCG berpengaruh signifikan positif dalam memoderasi IOS dan nilai perusahaan.

Penelitian ini merupakan adaptasi dari Lestari (2014) yang akan menguji pengaruh perencanaan pajak terhadap nilai perusahaan dengan kualitas corporate governance sebagai variabel moderasi. Perusahaan dengan corporate governance yang baik memiliki aturan dan nilai yang jelas sehingga perencanaan pajak dapat diterima sebagai bentuk perilaku yang legal. Adapun perusahaan dengan corporate governance yang buruk memiliki kelemahan dalam pengawasan dan pengendalian internal sehingga perilaku perencanaan pajak dapat dimanfaatkan untuk kepentingan manajemen.

\section{TINJAUAN PUSTAKA}

Menurut Suandy (2008), perencanaan pajak adalah langkah awal dalam manajemen pajak. Pada tahap ini dilakukan pengumpulan dan penelitian terhadap peraturan perpajakan agar dapat diseleksi jenis tindakan penghematan pajak yang akan dilakukan. Zain (2008) mengungkapkan bahwa perencanaan pajak merupakan tindakan penstrukturan yang terkait dengan konsekuensi potensi pajaknya, yang tekanannya kepada pengendalian setiap transaksi yang ada konsekuensi pajaknya. Tujuannya adalah bagaimana pengendalian tersebut dapat mengefisiensikan jumlah pajak yang akan ditransfer ke pemerintah, melalui apa yang disebut sebagai penghindaran pajak, bukan penyelundupan pajak.

Good Corporate Governance merupakan sistem yang mengatur dan mengendalikan perusahaan yang menciptakan nilai tambah untuk semua stakeholders (Monks, 2003). Menurut FCGI (2001) Good Corporate Governance adalah seperangkat peraturan yang mengatur hubungan pemegang saham, pengelola perusahaan, pihak kreditur, pemerintah, karyawan, serta para pemegang kepentingan intern dan ekstern lainnya yang berkaitan dengan hak-hak dan kewajiban mereka.

Menurut Myers (1977), Investment Opportunity Set (IOS) merupakan keputusan investasi dalam bentuk kombinasi antara aktiva yang dimiliki dan pilihan investasi yang akan 
datang dengan Net Present Value (NPV) positif yang akan mempengaruhi nilai perusahaan. Menurut Gaver \& Gaver (1993), IOS merupakan nilai perusahaan yang besarnya tergantung pada pengeluaran-pengeluaran yang ditetapkan manajemen di masa mendatang, yang pada saat ini masih merupakan pilihan-pilihan investasi yang diharapkan akan menghasilkan return yang lebih besar. Secara umum dapat dikatakan IOS menggambarkan luasnya kesempatan atau peluang investasi bagi suatu perusahaan, namun sangat tergantung pada expenditure perusahaan untuk kepentingan di masa mendatang.

Menurut Irham (2015) nilai perusahaan adalah rasio nilai pasar yaitu rasio yang menggambarkan kondisi yang terjadi di pasar. Rasio ini mampu memberi pemahaman bagi pihak manajemen perusahaan terhadap kondisi penerapan yang akan dilaksanakan dan dampaknya pada masa mendatang. Menurut Sartono (2016) tujuan memaksimumkan kemakmuran pemegang saham dapat ditempuh dengan memaksimumkan nilai sekarang, atau present value semua keuntungan pemegang saham akan meningkat apabila harga saham yang dimiliki juga meningkat.

Wahab (2012) menyatakan bahwa perencanaan pajak berpengaruh negatif terhadap nilai perusahaan. Astriani (2014) menyatakan bahwa profitabilitas tidak berpengaruh terhadap nilai perusahaan, sedangkan IOS berpengaruh positif signifikan terhadap nilai perusahaan. Adapun Gustiandika \& Hadiprajitno (2014) menyatakan bahwa IOS berpengaruh positif signifikan terhadap nilai perusahaan, sedangkan GCG tidak berpengaruh dalam memoderasi pengaruh IOS terhadap nilai perusahaan.

Hidayat \& Hairi (2016) menemukan hubungan negatif signifikan antara perencanaan pajak terhadap nilai perusahaan. Pengaruh negatif ini didasari bahwa pihak investor menginginkan pengembalian yang tinggi dari hasil investasi mereka. Salah satu hasil investasi mereka adalah pembagian dividen yang dihitung dari laba perusahaan. Salah satu perencanaan pajak adalah dengan memperhatikan biaya-biaya yang dapat dikurangi dalam perhitungan fiskal pajak, yang dapat menyebabkan laba berkembang kurang signifikan. Dengan demikian menimbulkan agency cost yang berdampak pada tingkat kepercayaan investor terhadap nilai perusahaan. Widyaningrum (2017) menyatakan bahwa IOS berpengaruh negatif signifikan terhadap nilai perusahaan, sedangkan GCG berpengaruh positif signifikan dalam memoderasi pengaruh IOS terhadap nilai perusahaan.

Penelitian ini akan menguji pengaruh tax planning dan investment opportunity set terhadap nilai perusahaan, dengan disertakan corporate governance sebagai variabel pemoderasi. Hubungan antar variabel dapat dijelaskan sebagai berikut :

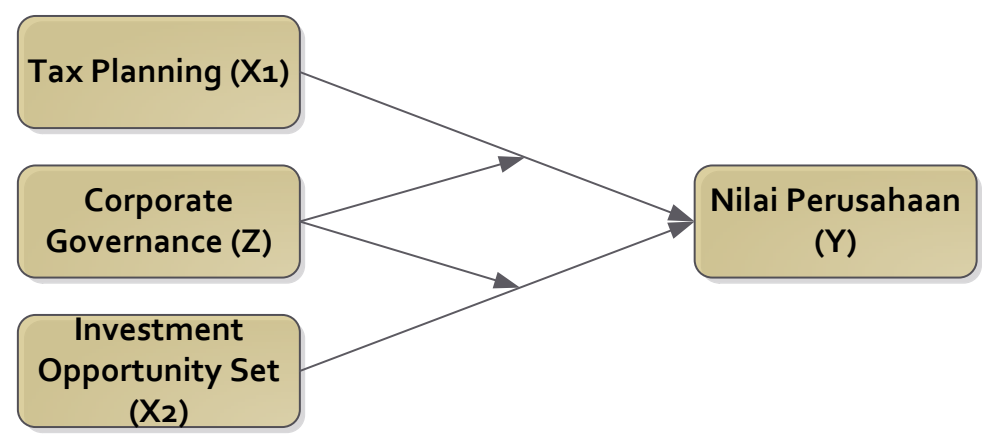

Gambar 2.1. Kerangka Pemikiran

Sumber: Dewanata \& Achmad (2017) dan Herlambang (2017). 
Pajak yang merupakan beban bagi perusahaan karena menjadikan laba berkurang. Perencanaan pajak berfungsi untuk mengatur dan menekan pajak perusahaan menjadi lebih rendah. Perusahaan melakukan perencanaan pajak guna melakukan efisiensi pajak. Dengan efisiensi pajak, perusahaan mampu meningkatkan produktivitas dan kinerja demi kelangsungan hidupnya. Perencanaan pajak juga mampu meningkatkan nilai perusahaan. Semakin besar perencanaan pajaknya, semakin besar pula nilai perusahaannya. Perencanaan pajak dapat meningkatkan laba sehingga nilai perusahaan dapat meningkat. Nilai perusahaan dapat diidentifikasi antara lain dari harga saham. Jika harga saham tinggi, maka kesejahteraan pemegang sahamnya juga tinggi; demikian pula sebaliknya. Laba yang tinggi memungkinkan perusahaan memberikan dividen yang besar. Harga saham yang tinggi berdampak pada dividen yang besar. Dengan demikian nilai perusahaan akan meningkat jika harga saham tinggi diikuti dengan laba yang besar (Dewanata \& Achmad, 2017). Berdasarkan tinjauan pustaka tersebut, maka dirumuskan hipotesis pertama sebagai berikut :

$\mathrm{H}_{1}$ : Tax Planning berpengaruh terhadap Nilai Perusahaan.

Berdasarkan Signalling Theory, terjadinya pengeluaran perusahaan untuk kegiatan investasi akan memberikan sinyal positif bagi investor, karena investor mempunyai persepsi bahwa perusahaan peduli akan masa depannya sendiri sehingga perusahaan memiliki prospek yang baik untuk jangka panjang. Adanya peningkatan jumlah aktiva tetap oleh perusahaan merupakan contoh kegiatan investasi yang dilakukan oleh perusahaan. Adanya peningkatan jumlah aktiva tetap tersebut mengindikasikan bahwa perusahaan memiliki pertumbuhan investasi yang bagus, diharapkan dari adanya kegiatan investasi tersebut diharapkan perusahaan akan memperoleh keuntungan atau return yang dapat memakmurkan pemegang saham. Persepsi tersebut akan membuat harga ekuitas suatu perusahaan meningkat sehingga nilai perusahaan akan meningkat (Herlambang, 2017). Berdasarkan tinjauan pustaka tersebut, maka dirumuskan hipotesis kedua sebagai berikut: $\mathrm{H}_{2}$ : Investment Opportunity Set berpengaruh terhadap Nilai Perusahaan.

Corporate governance digunakan sebagai dasar, pedoman atau nilai bagi komisaris, manajemen, direksi dan karyawan dalam menjalankan operasional perusahaan. Corporate governance dibuat untuk dapat dipatuhi dan dijalankan oleh masing-masing individu dalam perusahaan. Tanpa adanya corporate governance, perusahaan akan kehilangan arah untuk mencapai tujuan perusahaan. Untuk itu corporate governance digunakan dalam penelitian ini sebagai variabel moderasi untuk mengarahkan hubungan perencanaan pajak sehingga dapat mencapai nilai perusahaan yang baik.

Keterkaitan perencanaan pajak terhadap nilai perusahaan tidak sepenuhnya mulus. Terdapat hambatan dalam perencanaan pajak untuk dapat meningkatkan nilai perusahaan. Perencanaan pajak yang dilakukan memberikan peluang bagi manajemen untuk mendapatkan keuntungannya sendiri. Dengan adanya tindakan tersebut, perencanaan pajak dapat menurunkan nilai perusahaan sehingga dibutuhkan corporate governance sebagai pengendalian internal dan pengawasan perusahaan. Good corporate governance diperlukan dalam mengurangi konflik kepentingan antara pemegang saham dan manajemen. Corporate Governance menerapkan lima prinsip utama, yaitu Transparansi, Akuntabilitas, Independensi, Responsibilitas, serta Kewajaran dan Kesetaraan. Adanya lima prinsip tersebut menguatkan jati diri Corporate Governance dalam membangun perusahaan yang baik dan bersih dari segala bentuk penyimpangan (Dewanata \& Achmad, 2017). Berdasarkan tinjauan pustaka tersebut, maka dirumuskan hipotesis ketiga sebagai berikut : 
$\mathrm{H}_{3}$ : Good Corporate Governance memperkuat pengaruh Tax Planning terhadap Nilai Perusahaan.

Keputusan investasi adalah salah satu keputusan keuangan yang dapat meningkatkan nilai perusahaan. Keputusan investasi merupakan keputusan yang diambil oleh manajer keuangan dalam mengalokasikan dana perusahaan ke dalam bentuk-bentuk investasi. Keputusan investasi harus dipertimbangkan secara cermat agar memberikan manfaat di masa mendatang. Keputusan investasi membantu manajer dalam menggunakan sumber daya secara efisien. Jadi semakin efisien perusahaan menggunakan sumber dayanya, maka semakin besar pula kepercayaan dari calon investor untuk membeli sahamnya (Widyaningrum, 2017).

Adanya Investment Opportunity Set yang didukung dengan Good Corporate Governance akan menjadi sinyal yang positif bagi investor. Hal tersebut akan membuat para pemilik perusahaan semakin percaya dengan pihak manajemen perusahaan dalam keputusan investasinya, atau tidak ada penyalahgunaan dana investasi perusahaan oleh manajemen perusahaan. Dengan demikian kepercayaan investor dapat meningkatkan nilai perusahaan (Widyaningrum, 2017). Berdasarkan tinjauan pustaka tersebut, maka dirumuskan hipotesis keempat sebagai berikut:

$\mathrm{H}_{4}$ : Good Corporate Governance memperkuat pengaruh Investment Opportunity Set terhadap Nilai Perusahaan.

\section{METODE PENELITIAN}

Populasi dalam penelitian ini adalah seluruh perusahaan yang terdaftar di Bursa Efek Indonesia dan termasuk dalam Indeks LQ45. Sampel dipilih dengan menggunakan metode purposive sampling dengan beberapa kriteria tertentu :

1. Perusahaan yang terdaftar di Bursa Efek Indonesia dan masuk dalam kriteria Indeks LQ45.

2. Perusahaan menerbitkan laporan keuangan secara tepat waktu dan berturut-turut selama periode 2014-2018.

3. Perusahaan memiliki kelengkapan data yang dibutuhkan dalam penelitian ini berturutturut selama periode 2014-2018.

Nilai Perusahaan diproksikan dengan menggunakan Tobin's $Q$ yang diukur dengan menggunakan rumus sebagai berikut :

Tobin's $Q=\frac{\text { (Harga Saham Penutupan x Jumlah Saham Beredar)+Total Hutang }}{\text { Total Ekuitas+Total Hutang }}$

Tax Planning diukur dengan menggunakan rumus Effective Tax Rate (ETR) dengan rumus sebagai berikut :

$\mathrm{ETR}=\frac{\text { Beban Pajak Penghasilan }}{\text { Laba sebelum pajak }}$

Investment Opportunity Set diukur dengan menggunakan Book Value dari Aktiva Tetap dengan rumus sebagai berikut (Atmajaya, 2008) :

BVA $=\frac{\text { Aset Tetap } t-\text { Aset Tetap } t-1}{\text { Jumlah Aset }}$

Good Corporate Governance diukur dengan metode yang digunakan untuk menilai Corporate Governance Disclosure Index (CGDI) yaitu nilai 1 untuk item yang diungkapkan 
dan nilai 0 untuk item yang tidak diungkapkan. Selanjutnya, CGDI dihitung dengan rumus (Bhuiyan \& Biswas, 2007) :

$\mathrm{CGDI}=\frac{\text { Total skor yang diungkapkan }}{\text { Skor Maksimum }}$

Metode analisis data yang digunakan adalah dengan menggunakan metode regresi data panel. Data panel adalah gabungan antara data silang dengan data runtun waktu (Gujarati, 2012). Dengan pengamatan berulang terhadap data silang yang cukup, analisis data panel memungkinkan seseorang mempelajari dinamika perubahan dengan data runtun waktu. Model regresi data panel yang digunakan untuk menguji pengaruh Tax Planning, Investment Opportunity Set, dan dampak moderasi dari Good Corporate Governance terhadap Nilai Perusahaan, adalah sebagai berikut :

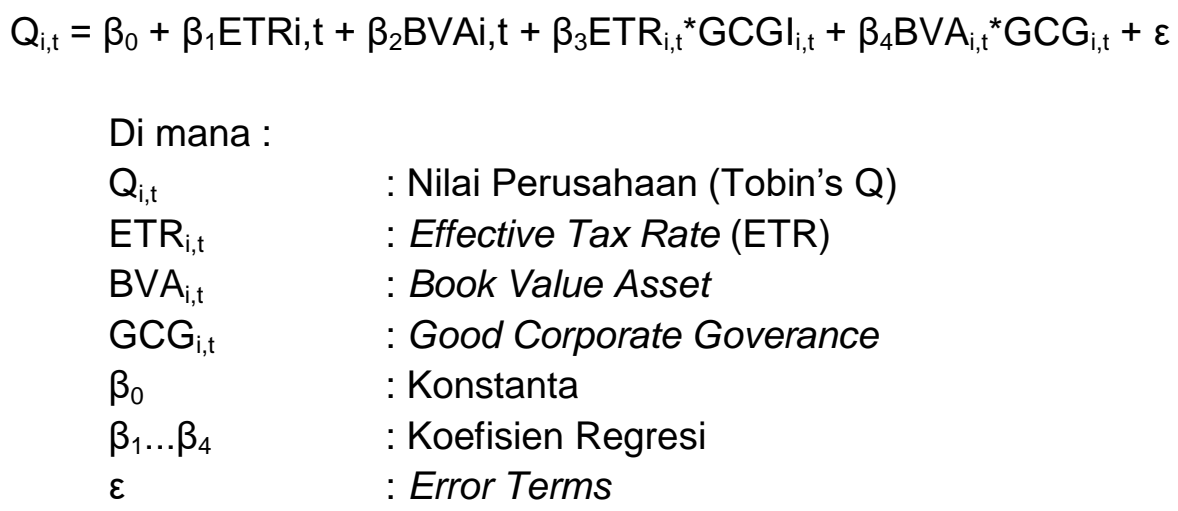

\section{HASIL DAN PEMBAHASAN}

Berdasarkan statistik deskriptif pada Tabel 1 diketahui bahwa variabel Tobins $Q$ nilai rata-rata adalah 1,3926, nilai maximum adalah 0,26899, nilai minimum adalah 0,6376 , dan standar deviasi adalah 0,4674. Variabel Effective Tax Rate memiliki nilai rata-rata adalah 0,2758 , nilai maximum adalah 3,8621 , nilai minimum adalah $-0,7925$, dan standar deviasi adalah 0,4159. Variabel Book Value Asset nilai rata-rata adalah 0,02312, nilai maximum adalah 0,2517 , nilai minimum adalah $-0,0403$, dan standar deviasi adalah 0,0422. Variabel interaksi antara Effective Tax Rate dan Good Corporate Governance nilai rata-rata adalah 23,2048 , nilai maximum adalah 343,73 , nilai minimum adalah $-59,4416$, dan standar deviasi adalah 36,5345. Sementara itu, variabel interaksi antara Book Value Asset dan Good Corporate Governance memiliki nilai rata-rata adalah 1,9418, nilai maksimum adalah 19,981 , nilai minimum adalah $-3,3849$, dan standar deviasi adalah 3,4718 .

Tabel 1. Statistik Deskriptif

\begin{tabular}{ccccc}
\hline Variabel & Rata-rata & Maximum & Minimum & Standar Deviasi \\
\hline TOBSQ & 1.3926 & 2.6899 & 0.6376 & 0.4674 \\
ETR & 0.2758 & 3.8621 & -0.7925 & 0.4159 \\
BVA & 0.02312 & 0.2517 & -0.0403 & 0.0422 \\
ETRGCG & 23.2048 & 343.73 & -59.4416 & 36.5354 \\
BVAGCG & 1.9418 & 19.891 & -3.3849 & 3.4718 \\
\hline
\end{tabular}

Sumber : Data diolah, 2019. 
Dalam regresi data panel, pemilihan model yang terbaik dengan tahap estimasi model Common Effect (CEM), Fixed Effect (FEM), dan Random Effect (REM). Tabel 2 menyatakan bahwa model yang terbaik untuk digunakan adalah model Fixed Effect. Berdasarkan uji Chow menunjukkan signifikan model Fixed Effect lebih baik dibandingkan Common Effect. Sementara itu uji Hausman menunjukkan signifikan Fixed Effect lebih baik dibandingkan Random Effect. Adapun hasil estimasi model regresi data panel disajikan dalam Tabel 3.

Tabel 2. Hasil Uji Chow dan Hausman

\begin{tabular}{ccc}
\hline Estimasi Model & Sig & Hasil \\
\hline Fixed Effect (FEM) & 0,000 & Fixed Effect \\
Random Effect (REM) & 0,003 & Fixed Effect \\
\hline
\end{tabular}

Sumber : Data diolah, 2019.

Tabel 3. Regresi Data Panel

\begin{tabular}{lrrr}
\hline \multicolumn{1}{c}{ Variabel } & Koefisien & t-Statistic & \multicolumn{1}{c}{ Prob. } \\
\hline C & 1,3413 & 24,9493 & 0,000 \\
ETR & 5,2737 & 2,4732 & 0,00795 \\
BVA & 39,0049 & 1,7509 & 0,04225 \\
ETR $^{*}$ GCG & $-0,0599$ & $-2,4719$ & 0,00795 \\
BVA $^{*}$ GCG & $-0,4710$ & $-1,7248$ & 0,0446 \\
\hline
\end{tabular}

Sumber : Data diolah, 2019.

Berdasarkan Tabel 3, maka persamaan Fixed Effect Model adalah sebagai berikut:

Tobins $\mathrm{Q}=1,3413+5,2737 \mathrm{ETR}+39,0049 \mathrm{BVA}-0,0599 \mathrm{ETR}{ }^{\star} \mathrm{GCG}-0,4710 \mathrm{BVA}{ }^{\star} \mathrm{GCG}+\mathrm{e}$

Nilai signifikansi pengaruh Tax Planning terhadap nilai perusahaan adalah 0,00795 lebih kecil daripada 0,05. Nilai koefisien Tax Planning sebesar 5,2737 menunjukkan bahwa terdapat pengaruh yang positif dan signifikan tax planning terhadap nilai perusahaan. Perencanaan pajak dapat meningkatkan laba sehingga nilai perusahaan dapat meningkat. Nilai perusahaan dapat diidentifikasi antara lain dari harga saham. Harga saham perusahaan tinggi, maka kesejahteraan pemegang sahamnya juga tinggi; begitu juga sebaliknya. Laba perusahaan yang tinggi akan mendorong perusahaan mampu memberikan dividen yang besar. Dengan demikian nilai perusahaan akan meningkat jika harga saham perusahaan tinggi, dan diikuti dengan laba yang besar (Dewanata \& Achmad, 2017).

Nilai signifikansi pengaruh variabel Investment Opportunity Set terhadap nilai perusahaan adalah 0,04225 lebih kecil daripada 0,05. Nilai koefisien Investment Opportunity Set sebesar 39,0049 menunjukkan terdapat pengaruh positif dan signifikan dari Investment Opportunity Set terhadap nilai perusahaan. Berdasarkan Signalling Theory, terjadinya pengeluaran kas untuk kegiatan investasi oleh perusahaan akan memberikan suatu sinyal positif bagi investor. Kegiatan investasi membuat investor berpersepsi bahwa perusahaan peduli akan masa depannya sehingga perusahaan memiliki prospek yang baik untuk jangka panjang (Herlambang, 2017).

Nilai signifikansi pengaruh moderasi Effective Tax Rate dan Good Corporate Government terhadap nilai perusahaan adalah 0,00795 lebih kecil daripada 0,05. Nilai 
koefisiennya sebesar -0,0599 menunjukkan adanya pengaruh moderasi negatif Good Corporate Government terhadap pengaruh Effective Tax Rate terhadap nilai perusahaan. Perencanaan pajak memberikan peluang bagi manajemen untuk mendapatkan keuntungan sendiri. Dengan alur tersebut, perencanaan pajak dapat menurunkan nilai perusahaan sehingga dibutuhkan Good Corporate Government sebagai pengendalian internal dan pengawasan perusahaan. Good Corporate Government diperlukan dalam mengurangi konflik kepentingan antara pemegang saham dan manajemen (Dewanata \& Achmad, 2017).

Nilai signifikansi pengaruh moderasi Investment Opportunity Set dan Good Corporate Government terhadap nilai perusahaan adalah 0,0446 lebih kecil daripada 0,05. Nilai koefisien sebesar -0,4710 menunjukkan bahwa Good Corporate Government dapat memoderasi secara negatif pengaruh Investment Opportunity Set terhadap nilai perusahaan. Adanya Investment Opportunity Set yang didukung dengan tata kelola perusahaan yang baik akan menjadi sinyal yang positif bagi investor. Hal tersebut akan membuat para pemilik perusahaan akan semakin percaya dengan pihak manajemen perusahaan dalam keputusan investasinya. Tidak adanya penyalahgunaan dana investasi perusahaan oleh manajemen perusahaan menumbuhkan kepercayaan investor sehingga meningkatkan nilai perusahaan (Widyaningrum, 2017).

\section{KESIMPULAN}

Berdasarkan hasil analisis dan pembahasan, maka dapat disimpulkan bahwa Tax Planning dan Investment Opportunity Set secara parsial memiliki pengaruh positif signifikan terhadap nilai perusahaan. Berdasarkan hal tersebut maka manajemen perusahaan perlu untuk meningkatkan Tax Planning dengan cara mengukur perencanaan pajak dengan lebih baik dan lebih akurat. Investment Opportunity Set juga perlu ditingkatkan dengan cara meningkatkan kinerja dan meningkatkan kepercayaan investor terhadap perusahaan.

Sementara itu hasil Good Corporate Government terbukti memoderasi pengaruh Tax Planning dan Investment Opportunity Set terhadap nilai perusahaan secara negatif. Hal ini tidak sejalan dengan penelitian sebelumnya, dimungkinkan karena perusahaan sampel hanya terbatas pada yang terdaftar Indeks LQ-45 yang kinerjanya baik, dan nilai perusahaan lebih didorong peningkatan kinerja finansial.

Penelitian selanjutnya dapat mempertimbangkan untuk melakukan penelitian pada perusahaan lainnya, misanya pada perusahaan manufaktur yang meliputi subsektor yang sangat beragam, serta menambah variabel lainya yang belum ada dalam penelitian ini.

\section{DAFTAR PUSTAKA}

Astriani, E. F., (2014). Pengaruh Kepemilikan Manajerial, Leverage, Profitabilitas, Ukuran Perusahaan, dan Invesment Opportunity Set Terhadap Nilai Perusahaan. Skripsi, Universitas Padang.

Dewanata, P. (2016). Pengaruh Perencanaan Pajak terhadap Nilai Perusahaan dengan Kualitas Corporate Governance sebagai Variabel Moderasi. Skripsi, Universitas Diponegoro. Semarang 
Fahmi, I (2015). Pengantar Manajemen Keuangan Teori dan Soal Jawab. Bandung: Alfabeta.

FCGI. (2001). Seri Tata Kelola Perusahaan (Corporate Governance). Edisi ke-2. Jakarta.

Gaver, J., \& Gaver, K. M. (1993). Additional Evidence on the Association between the Investment Opportunity Set and Corporate Financing, Dividen, and Compensation Policies. Journal of Accounting \& Economics, 1, p.125-160.

Gujarati, D. (2012). Dasar-Dasar Ekonometrika. Edisi Lima. Jakarta : Salemba Empat.

Gustiandika, T. \& Hadiprajitno, P.B. (2014). Pengaruh Keputusan Investasi dan Keputusan Pendanaan terhadap Nilai Perusahaan dengan Corporate Governance Sebagai Variabel Moderasi. Diponegoro Journal Of Accounting, 3(2), p.1141-1152.

Herlambang, P.S (2017). Pengaruh Corporate Governance dan Rasio Keuangan terhadap Financial Distress pada Perusahaan Manufaktur yang Terdaftar di Bursa Efek Indonesia. Majalah Ekonomi, 22(2).

Hidayat, M. \& Hairi, M I. A. (2016). Pengaruh Perencanaan Pajak dan Modal Intelektual terhadap Nilai Perusahaan pada Perusahaan Jasa Keuangan yang Terdaftar di Bursa Efek Indonesia Periode 2009-2013. Jurnal IImiah Ekonomi Global Masakini, 7(2), p: 23-29.

Kristanto, D. \& Alfret et al. (2017). Pengaruh Rasio Leverage dan Profitabilitas terhadap Nilai Perusahaan Industri Makanan dan Minuman yang Terdaftar di Bursa Efek Indonesia. Jurnal IImu Manajemen Universitas Tadulako, 3(1), p.39-54.

Monks, R. A. G \& Minow, N. (2003). Corporate Governance. Third Edition. Blackwell Publishing.

Myers, S. (1977). Determinant of Corporate Borrowing. Journal of Financial Economics, 5(2), p.147-175.

Lestari, N. R. W. (2014). Pengaruh Perencanaan Pajak Terhadap Nilai Perusahaan dengan Moderasi Corporate Governance. Simposium Nasional Akuntansi 17. Lombok.

Pratiska, N. G. A. \& Putu, S. (2013). Pengaruh Investment Opportunity Set, Leverage, dan Dividend Yield terhadap Profitabilitas dan Nilai Perusahaan Sektor Manufaktur di BEI. E-Jurnal Ekonomi dan Bisnis Universitas Udayana, 2(3).

Rizqia, D. A, Siti, A. \& Sumiati. (2013). Effect of Managerial Ownership, Financial Leverage, Profitability, Firm Size, and Investment Opportunity on Dividend Policy and Firm Value. Research Journal of Finance and Accounting, 4(11).

Sartono, Agus. (2015). Manajemen Keuangan : Teori dan Aplikasi. Edisi Keempat. Yogyakarta: BPFE.

Suandy, E. (2011). Perencanaan Pajak. Edisi 5. Jakarta : Salemba Empat.

Wahab, S. A. (2012) Analisis Kebijakan dari Formulasi ke Penyusunan Model-Model Implementasi Kebijakan Publik. Jakarta: Bumi Aksara.

Widyaningrum, N. (2017). Pengaruh Keputusan Investasi, Keputusan Pendanaan, dan Kinerja Keuangan terhadap Nilai Perusahaan dengan Good Corporate Governance sebagai Variabel Moderasi (Studi Empiris pada Perusahaan yang Terdaftar di Bursa Efek Indonesia dan Masuk Peringkat CGPI Periode 2013-2015. Disertasi, Universitas Muhammadiyah Surakarta.

Winarno, W. W. (2015). Analisis Ekonometrika dan Statistika dengan Eviews. Yogyakarta: UPP STIM YKPN. 